\title{
Study on decision making of fresh food supplier selection
}

\author{
Shimin Wang, and Zhimin $\mathrm{Du}^{*}$ \\ Beijing Technology and Business University, Beijing 100048, China
}

\begin{abstract}
As the first process of the supply chain, fresh food supplier is the source of food safety, and also the key factor of the whole fresh food supply chain competition. AHP is used to establish the fresh food supplier selection index system. IT is used to calculate the weight of each evaluation index. Through the establishment of a comprehensive evaluation model, decision maker will comprehensively evaluate the strength of fresh food suppliers.
\end{abstract}

Keywords: Supplier selection, Analytic hierarchy process, Fresh food.

\section{Introduction}

At the early of COVID-19, some fresh food surface were detected COVID-19. Therefore, how to ensure the safety of fresh food has become the most concerned topic. In order to ensure the safety of fresh food, fresh food operators should consider suppliers more comprehensively when selecting suppliers. This paper attempts to establish a comprehensive and systematic index system to reflect the supplier selection and evaluation, which can adapt to the current development, and is expected to provide decision-making support and reference for fresh food enterprises.

The analytic hierarchy process (AHP), proposed by the famous American scholar Professor T.L.Saaty in the 1970s, is a method based on multi-criteria decision-making. The method which integrated qualitative analysis and quantitative analysis is applied to determine the weight of each index in the process of decision-making and planning. It has the advantages of practicality, systematicness and simplicity. The main processes are as follows: (1)build the construction of index system; (2)establish the pairwise comparison judgment matrix; (3)conduct single hierarchical arrangement; (4)conduct total taxis of hierarchy.

\section{Establishment of fresh food supplier selection model}

This paper selects some indexes to evaluate the strength of fresh suppliers, and uses AHP to transform them into quantitative indexes for calculation. And then, decompose the factors

\footnotetext{
* Corresponding author: wangsm@btbu.edu.cn
} 
into several hierarchies, conduct pairwise comparison judgment matrix, determine the relatively important factors in the hierarchies. Finally, the importance of each factor is integrated to rank the total service capacity. so as to evaluate the comprehensive strength of fresh suppliers and select the appropriate fresh suppliers.

\subsection{Chicken product supply chain}

The construction of index system is the benchmark of evaluation and calculation. The construction ideas of supplier selection evaluation index system are as follows: first, based on the previous research of supplier selection evaluation system, through the analysis of the connotation of supplier selection evaluation, the basic elements of fresh supplier are determined, and all elements are comprehensively considered.According to the principle of determining the index, the initial index system is designed.Second, adjust the initial index system according to the characteristics of the epidemic period to make it more in line with the actual situation.Finally, a fresh supplier selection index system is formed, which includes four first-class indexes such as product quality, product price, supply capacity and supplier strength, as well as 14 second-class indexes such as freshness quality qualification rate and unit product price, as shown in Table 1.

Table 1. Fresh supplier selection rating index system.

\begin{tabular}{|c|c|c|c|}
\hline Target layer & Criterion layer & Index layer & Index attribute \\
\hline \multirow{14}{*}{$\begin{array}{l}\text { Choose the } \\
\text { best supplier }\end{array}$} & \multirow{2}{*}{$\begin{array}{l}\text { Product quality } \\
\text { B1 }\end{array}$} & Freshness $\mathrm{C} 1$ & qualitative \\
\hline & & Quality pass rate $\mathrm{C} 2$ & ration \\
\hline & \multirow{3}{*}{ Product price B2 } & Unit product price $\mathrm{C} 3$ & ration \\
\hline & & Volume discount rate $\mathrm{C} 4$ & qualitative \\
\hline & & Order cost $\mathrm{C} 5$ & ration \\
\hline & \multirow{4}{*}{$\begin{array}{c}\text { Supply capacity } \\
\text { B3 }\end{array}$} & Order satisfaction rate $\mathrm{C} 6$ & ration \\
\hline & & Timeliness of delivery C7 & ration \\
\hline & & Quick response C8 & ration \\
\hline & & $\begin{array}{l}\text { Emergency distribution capacity } \\
\text { C9 }\end{array}$ & qualitative \\
\hline & \multirow{5}{*}{$\begin{array}{l}\text { Supplier strength } \\
\text { B4 }\end{array}$} & Enterprise scale $\mathrm{C} 10$ & qualitative \\
\hline & & $\begin{array}{c}\text { Cold chain logistics facilities and } \\
\text { equipment } \mathrm{C} 11\end{array}$ & qualitative \\
\hline & & $\begin{array}{l}\text { Enterprise information system } \\
\mathrm{C} 12\end{array}$ & qualitative \\
\hline & & $\mathrm{R} \& \mathrm{D}$ capability $\mathrm{C} 13$ & qualitative \\
\hline & & Quality traceability system C14 & qualitative \\
\hline
\end{tabular}




\subsection{Construct the judgment matrix and determine the weight and consistency test}

In this study, a group of 20 experts, including industry experts and logistics graduate students, were invited to analyze and compare the evaluation indexes of fresh food suppliers formed in the study, and the evaluation indexes were ranked anonymously according to the degree of importance. According to the collected expert consultation data, the geometric mean method is used to collect and calculate, and the comprehensive judgment matrix is obtained. Then, the weight of the matrix is calculated by the sum product method and the consistency is tested. The steps are as follows:

1. The steps of weight calculation by sum product method are as follows:

(1) Normalize each column element of judgment matrix

(2) The normalized judgment matrix of each column is added by row

(3) Pair vector $\mathrm{W}^{\prime}=\left(\mathrm{W}_{1}^{\prime}, \mathrm{W}_{2}^{\prime} \ldots \ldots \mathrm{W}_{\mathrm{n}}^{\prime}\right)^{\mathrm{t}}$ After normalization, the eigenvector $\mathrm{W}$ is obtained $\mathrm{W}=\left(\mathrm{W}_{1}, \mathrm{~W}_{2} \ldots \ldots \mathrm{W}_{\mathrm{n}}\right)^{\mathrm{t}}$

(4) Calculating the maximum eigenvalue of judgment matrix $\lambda_{\max }$

2. Procedure of consistency test

Because the evaluation of the judgment matrix is subjective, it is necessary to introduce the correction value RI to check the consistency of the judgment matrix.

$$
\begin{gathered}
\mathrm{CI}=\frac{\lambda_{\max }-\mathrm{n}}{\mathrm{n}-1} \\
\mathrm{CR}=\frac{\mathrm{CI}}{\mathrm{RI}}
\end{gathered}
$$

Among them, Clis the consistency index, nis the order of judgment matrix,CR is the consistency proportion, and RI is the average random consistency index of the same order . $\mathrm{CR}=\frac{\mathrm{CI}}{\mathrm{RI}}<0.1$ It means that the judgment matrix is consistent.

According to the above steps, table 2-6 is the results of the weight of each judgment matrix and the consistency.

\begin{tabular}{|c|c|c|c|c|c|c|}
\hline Index & B1 & B2 & B3 & B4 & Weight & Consistency test \\
\hline $\mathrm{B} 1$ & 1 & 2 & 3 & 4 & 0.4596 & \multirow{4}{*}{$\begin{array}{c}\lambda \max =4.0459 \\
\mathrm{CI}=0.0153 \\
\mathrm{RI}=0.89 \\
\mathrm{CR}=0.0172<0.1\end{array}$} \\
\hline B2 & $1 / 2$ & 1 & 2 & 4 & 0.2945 & \\
\hline B3 & $1 / 3$ & $1 / 2$ & 1 & 2 & 0.1572 & \\
\hline B4 & $1 / 4$ & $1 / 4$ & $1 / 2$ & 1 & 0.0886 & \\
\hline
\end{tabular}

Table 2. Judgment matrix, weight and consistency test of criterion layer for target layer.

Table 3. Judgment matrix, weight and consistency test of secondary indicators of B1 and C.

\begin{tabular}{|c|c|c|c|c|}
\hline B1 & C1 & C2 & Weight & Consistency test \\
\hline $\mathrm{C} 1$ & 1 & $1 / 2$ & 0.3333 & $\lambda \max =2, \mathrm{CI}=0$ \\
$\mathrm{y} 2$ & 2 & 1 & 0.6667 & $\mathrm{RI}=0, \mathrm{CR}=0<0.1$ \\
\hline
\end{tabular}

\begin{tabular}{|c|c|c|c|c|c|}
\hline B2 & $\mathrm{C3}$ & $\mathrm{C4}$ & $\mathrm{C5}$ & Weight & Consistency test \\
\hline $\mathrm{C} 3$ & 1 & 2 & 3 & 0.5247 & \multirow{3}{*}{$\begin{array}{c}\lambda \max =3.0538 \\
\mathrm{CI}=0.0269, \mathrm{RI}=0.52 \\
\mathrm{CR}=0.0517<0.1\end{array}$} \\
\hline $\mathrm{C} 4$ & $1 / 2$ & 1 & 3 & 0.3338 & \\
\hline C5 & $1 / 3$ & $1 / 3$ & 1 & 0.1416 & \\
\hline
\end{tabular}

Table 4. Judgment matrix, weight and consistency test of secondary indicators of B2 and C. 
Table 5. Judgment matrix, weight and consistency test of secondary indicators of B3 and C.

\begin{tabular}{|c|c|c|c|c|c|c|}
\hline B3 & C6 & C7 & C8 & C9 & Weight & Consistency test \\
\hline C6 & 1 & 2 & 4 & 5 & 0.4896 & \multirow{4}{*}{$\begin{array}{c}\lambda \max =4.0669 \\
\mathrm{CI}=0.0223 \\
\mathrm{RI}=0.89 \\
\mathrm{CR}=0.0250<0.1\end{array}$} \\
\hline $\mathrm{C} 7$ & $1 / 2$ & 1 & 3 & 4 & 0.3054 & \\
\hline $\mathrm{C} 8$ & $1 / 4$ & $1 / 3$ & 1 & 2 & 0.1264 & \\
\hline $\mathrm{C} 9$ & $1 / 5$ & $1 / 4$ & $1 / 2$ & 1 & 0.0786 & \\
\hline
\end{tabular}

Table 6. Judgment matrix, weight and consistency test of secondary indicators of B4 and C.

\begin{tabular}{|c|c|c|c|c|c|c|c|}
\hline B4 & C10 & C11 & $\mathrm{C12}$ & C13 & C14 & Weight & Consistency test \\
\hline $\mathrm{C} 10$ & 1 & 2 & 5 & 4 & 3 & 0.4154 & \multirow{5}{*}{$\begin{array}{c}\lambda \max =5.1407 \\
\mathrm{CI}=0.0352 \\
\mathrm{RI}=1.12 \\
\mathrm{CR}=0.0314<0.1\end{array}$} \\
\hline $\mathrm{C} 11$ & $1 / 2$ & 1 & 4 & 3 & 2 & 0.2613 & \\
\hline $\mathrm{C} 12$ & $1 / 5$ & $1 / 4$ & 1 & $1 / 3$ & $1 / 2$ & 0.0638 & \\
\hline $\mathrm{C} 13$ & $1 / 4$ & $1 / 3$ & 3 & 1 & $1 / 2$ & 0.1119 & \\
\hline C14 & $1 / 3$ & $1 / 2$ & 2 & 2 & 1 & 0.1476 & \\
\hline
\end{tabular}

\subsection{Hierarchical comprehensive sorting}

By sorting out the above data, we can get a weight value of B-C evaluation index layer relative to the total goal in Table 7.

Table 7. The ranking weight value of fresh supplier indexes on the total objective.

\begin{tabular}{|c|c|c|c|c|c|}
\hline Target layer & Criterion layer & Weight & Index layer & Weight & Comprehensive weight \\
\hline \multirow{14}{*}{$\begin{array}{l}\text { Fresh } \\
\text { supplier } \\
\text { selection } \\
\text { and rating } \\
\text { index } \\
\text { system }\end{array}$} & \multirow{2}{*}{$\mathrm{B} 1$} & \multirow{2}{*}{0.4596} & $\mathrm{C} 1$ & 0.3333 & 0.1532 \\
\hline & & & $\mathrm{C} 2$ & 0.6667 & 0.3064 \\
\hline & \multirow{3}{*}{ B2 } & \multirow{3}{*}{0.2945} & $\mathrm{C} 3$ & 0.5247 & 0.1545 \\
\hline & & & $\mathrm{C} 4$ & 0.3338 & 0.0983 \\
\hline & & & $\mathrm{C} 5$ & 0.1416 & 0.0417 \\
\hline & \multirow{4}{*}{ B3 } & \multirow{4}{*}{0.1572} & C6 & 0.4896 & 0.0770 \\
\hline & & & $\mathrm{C} 7$ & 0.3054 & 0.0480 \\
\hline & & & $\mathrm{C} 8$ & 0.1264 & 0.0199 \\
\hline & & & C9 & 0.0786 & 0.0124 \\
\hline & \multirow{5}{*}{ B4 } & \multirow{5}{*}{0.0886} & $\mathrm{C} 10$ & 0.4154 & 0.0368 \\
\hline & & & $\mathrm{C} 11$ & 0.2613 & 0.0232 \\
\hline & & & $\mathrm{C} 12$ & 0.0638 & 0.0057 \\
\hline & & & $\mathrm{C} 13$ & 0.1119 & 0.0099 \\
\hline & & & $\mathrm{C} 14$ & 0.1476 & 0.0131 \\
\hline
\end{tabular}

\section{Empirical research}

Take a fresh food company as an example, there are three alternative suppliers, which are replaced by G1, G2 and G3 respectively. The evaluation team composed of company experts scores the alternative suppliers according to the actual situation, and finally obtains the scores of each evaluation index of the three alternative suppliers. The scores are brought 
into the established evaluation model to obtain the final score of the supplier, and the score results are summarized in Table 8.

Table 8. Supplier score summary.

\begin{tabular}{|c|c|c|c|c|}
\hline Criterion layer & Index layer & G1 & G2 & G3 \\
\hline \multirow{2}{*}{ B1 } & $\mathrm{C} 1$ & 9 & 8 & 8 \\
\hline & $\mathrm{C} 2$ & 8 & 8 & 7 \\
\hline \multirow{3}{*}{ B2 } & $\mathrm{C} 3$ & 6 & 8 & 9 \\
\hline & $\mathrm{C} 4$ & 8 & 9 & 9 \\
\hline & $\mathrm{C} 5$ & 7 & 7 & 6 \\
\hline \multirow{4}{*}{ B3 } & C6 & 8 & 8 & 9 \\
\hline & $\mathrm{C} 7$ & 7 & 7 & 8 \\
\hline & $\mathrm{C} 8$ & 6 & 8 & 7 \\
\hline & C9 & 8 & 7 & 7 \\
\hline \multirow{5}{*}{ B4 } & $\mathrm{C} 10$ & 9 & 8 & 7 \\
\hline & C11 & 8 & 8 & 7 \\
\hline & $\mathrm{C} 12$ & 7 & 8 & 7 \\
\hline & $\mathrm{C} 13$ & 8 & 6 & 6 \\
\hline & $\mathrm{C} 14$ & 8 & 7 & 6 \\
\hline \multicolumn{2}{|c|}{ Total } & 7.7459 & 7.9633 & 7.7961 \\
\hline \multicolumn{2}{|c|}{ Ranking } & 3 & 1 & 2 \\
\hline
\end{tabular}

According to the results in Table 8, among the three alternative suppliers, the final ranking result is: supplier G2 > Supplier G3 > Supplier G1. In the consideration of suppliers, the result of this round of analysis is that company A prefers to choose G2 as its supplier and form a strategic partnership with it, so as to reach a long-term strategic cooperation intention and increase mutual trust. In order to avoid asymmetry information, they can establish information sharing platform to reduce cost and delivery time.

According to the research results, the following suggestions are put forward for the future fresh food suppliers. Firstly, suppliers should balanced development to avoid seeking to improve the quality or reduce the price blindly. Secondly, they should update cold chain logistics facilities and equipment in time to ensure the quality of products. Thirdly, they should improve the enterprise information system, so that real-time sharing improves the efficiency of procurement.

\section{Conclusion}

In this paper, combined AHP with the characteristics of the epidemic, trying to establish a suitable evaluation index system of fresh suppliers in the epidemic era, to select the most suitable supplier. Through the example analysis, it proves the feasibility of the model, which has a certain guiding value in practical application. In theory, no supplier selection model is universal, and supplier selection is a dynamic process. We should adjust it according to the actual situation on the basis of the results calculated by the model.

\section{References}

1. Li Jiarun. Supplier selection evaluation and Countermeasures of fresh supermarket [D]. Dalian: Dalian Jiaotong University, 2018

2. Zhang Yi, Yuan Ying, di long. Evaluation and selection of fresh food suppliers in large supermarkets $[\mathrm{J}]$. Science and Technology Bulletin, 2017 
3. Zhang Juxi, Wang Wenjuan. Research on evaluation index system of international first-class new mainstream media based on analytic hierarchy process [J]. Modern communication, 2020

4. Wan Xin, Zhao Shuguang, et al. Study on supplier selection strategy based on analytic hierarchy process $[\mathrm{J}]$. Journal of Liaoning University of Technology (NATURAL SCIENCE EDITION), 2020 